\title{
Reflections on Implementation of International Financial Reporting Standards (IFRS) in the Indian Banking Industry
}

\author{
Samrudha Nayak*, B. C. M. Patnaik, Ipseeta Satpathy \\ School of Management, KIIT University, India \\ Received October 14, 2020; Revised November 23, 2020; Accepted December 13, 2020
}

\section{Cite This Paper in the following Citation Styles}

(a): [1] Samrudha Nayak, B. C. M. Patnaik, IpseetaSatpathy, "Reflections on Implementation of International Financial Reporting Standards (IFRS) in the Indian Banking Industry," Universal Journal of Accounting and Finance, Vol. 8, No. 4, pp. 148 - 152, 2020. DOI: 10.13189/ujaf. 2020. 080407.

(b): Samrudha Nayak, B. C. M. Patnaik, IpseetaSatpathy (2020).Reflections on Implementation of International Financial Reporting Standards (IFRS) in the Indian Banking Industry. Universal Journal of Accounting and Finance, 8 (4), 148 - 152. DOI: 10.13189/ujaf. 2020. 080407.

Copyright $\subseteq 2020$ by authors, all rights reserved. The authors agree that this article remains permanently open access under the terms of the Creative Commons Attribution License 4.0 International License

\begin{abstract}
The purpose of this article is to study the preparedness of the Indian financial system to adopt the "International Financial Reporting Standard" (IFRS). IFRS, which is enunciated by the International Accounting Standards Board (IASB), describes how corporations have to manage their accounts and report on them. Created to establish a common accounting language, the goal of IFRS is to make financial statements consistent and uniform throughout the globe and across different industries in varying business environments. Although the study covers the implications of IFRS on various segments of commercial activities carried on in India, its focus was concentrated on the country's banking system. India has a multi-layered banking system which is predominantly owned by the government. With a history of more than 100 years, the Indian banks are the oldest of all the entities engaged in the business of financial intermediation in the country. No other sector of the Indian economy can match the contributions made by the Indian banks to the economic development of the nation. In the process of conducting the study, efforts have been made to examine and analyze the possible effects of those prescribed financial standards of IFRS which will substantially alter the hitherto followed accounting and reporting practices of the banks in India and its implications on the various stakeholders of the Indian banking system. The convergence of the Indian Financial Reporting Standards - the IND AS - with the International Financial Reporting Standards - IFRS - has not been a smooth sailing transition, despite the best efforts
\end{abstract}

of the Reserve Bank of India, which is the regulator in the Indian banking industry as the country's central bank.

Keywords Indian Financial Reporting Standard, Banks, Convergence of Indian Financial Reporting Standard, Finance, Industry, Financial Statements

\section{Background of the Study}

In contemporary times, most of the countries having a stable financial system, are either using the International Financial Reporting Standards (IFRS) or making preparations for adopting those standards for disclosure and reporting of financial performances, as they want that the affairs of their corporates must be consistently and most transparently understood by all concerned across the geographies of the globe. More than 120 nations have already got themselves compliant with the International Financial Reporting Standards to date. The Ministry of Corporate Affairs of the Government of India has issued IFRS guidelines applicable to all the relevant institutions, barring the banking and insurance companies. Implementation of IFRS in Indian banks and insurance companies is being spearheaded by the Central Bank of India (Reserve Bank of India) and the Insurance Regulatory and Development Authority of India (IRDA). As contained in these guidelines, the concerned business 
entities are required to start recasting their financial reports in line with the IFRS in a phased manner, with effect from the $1^{\text {st }}$ of April 2011. The banks were similarly asked to make a transition to IFRS compliance with effect from the $1^{\text {st }}$ of April 2013. Phased manner compliance over a while was needed because the Indian Accounting Standards(ISA)needed to be in overall alignment with the IFRS formats. Then again, the Indian laws applicable to the country's corporate affairs needed to be suitably amended and updated to be in tune with the demands of the IFRS compliance, and feedbacks from the Indian industries were also to be heard to provide them with an enabling environment for a smooth and hassle-free transition to the new reporting formats [1]. All this was not possible to usher in one stroke. It has been observed that many countries have realized that an instant integration with the new accounting norms stipulated in IFRS is neither practicable nor desirable and that time is required for achieving the convergence. The time required by nations will vary across the world, depending on the business and bookkeeping practices prevalent in each country. The following factors will affect the pace of the transition:

1. Mapping the difference in the national accounting standards and the International Financial Reporting Standards. The divergence could be many, which have to be reconciled. The Indian accounting standards are in tune with the Generally Accepted Accounting Principles (GAAP) which are not wholly in alignment with IFRS.

2. Training and education of personnel for understanding and appreciation, compilation and comparison and disclosure and presentation of affairs and accounts of business entities in convergence with IFRS is a huge challenge.

3. Overhauling the national legal and regulatory framework in tune with the requirements of IFRS is a mammoth task in the hands of many governments and regulatory authorities across the world.

4. Taxation is a major hurdle in the path of transition to IFRS in several countries. Governments of countries, especially of the developing nations, would hardly be motivated to switch over to the IFRS model of disclosure and presentation if it results in a decline of their fiscal revenues.

5. Last but not the least, the IFRS has let loose a new method of recording the valuation of assets and liabilities. It is what is known as the "fair value", as distinguished from the "historical cost" method of valuation of assets and liabilities in the financial statements of corporate.

An aspect of the transition from the national to the IFRS model which needs careful monitoring is to ensure that the process of alignment of the crucial financial data of an institution from the nation into the new international model does not significantly alter the meaning and implications of those data. And that calls for much greater involvement and coordination among all the relevant departments of a business organization in the compilation, interpretation, consolidation, and publication of its financial affairs. Gone will be the days in which recording financial information and preparation of financial statements were the exclusive responsibility of only the finance and accounts section of a firm [2]. Under IFRS, it will be a large joint responsibility in which even the sales $\&$ marketing and research \&development wing of the firm may have to contribute their inputs. In the backdrop of these hurdles, full-fledged integration of the Indian Accounting Standards (Ind-AS) made by Institute of Chartered Accountants of India (ICAI) with International Financial Reporting Standards made by International Accounting Standards Board (IASB) has not yet been possible, even if the Indian regulatory authorities had asked all its business entities to start adopting the IFRS in a phased manner with effect from the $1^{\text {st }}$ of April 2011 [3].

As a full member of the International Federation of Accountants (IFAC), the ICAI takes due account of its inclusion into the IASB's International Financial Reporting Standards in formulating the Accounting Standards (AS) [4]. However, where it was appropriate to depart from IFRS, the AS was changed to such an extent because of the Indian conditions and practices. In addition, it is the ICAI 's responsibility not only to close the distance between its AS and IFRS by issuing new AS but also to ensure that the current AS is compliant with the international change in accounting issues. In reviewing the AS provided by the ICAI, the National Committee for the Accounting Standard (NACAS), established by the Union Government of India, takes into account the deviations, if any, from IFRS in the AS and recommends that the ICAI amend the AS wherever they find the deviations to be unacceptable [5]. Altogether 39 ASs have to date been formulated by the ICAI, which have all passed through this paraphernalia.

\section{Objectives of the Study}

- To understand the dynamics of IFRS

- To study the status of integration of Indian Banks Financial system with IFRS

- To contribute to the existing literature

\section{The Methodology of the Study}

The current research is focused on secondary data and numerous websites and libraries visited to collect the data for this purpose.

\section{Integration of Indian Banks' Financial System with IFRS:}

India has a multi-faceted banking system. It is the 
oldest of the entities in the country engaged in the business of financial intermediation. Its contribution to the economic development of India is second to none. Although it has a very humble origin in which it was engaged in the most traditional dealings of borrowings (by way of deposits) and lendings, with time, it has gone on engaging itself in several other modern and complicated businesses ever since the independence of the country in 1947 [6]. Today's banks in India, especially those owned by the Government, are known to have huge assets and liabilities at their disposal.

The Reserve Bank of India is the main regulator of Indian banks. RBI is empowered to control the financial accounts of banks and financial institutions by the Bank Regulation Act (1949). The forms of financial statements (e.g. balance sheets and profit \& loss accounts) and other accounting requirements are specified under one schedule of the Banking Regulation Act [7]. Banks of India shall also comply with the Companies Act (2013) specifications. From time to time the RBI has given banks guidance to comply with ICAI accounting standards. The majority of India's major banks are listed in the country's stock exchanges. In all of India's listed banks, the divulgation and reporting conditions are laid down in its Act of 1992 and the 1956 Securities Contracts Regulation Act, which governs the securities trading of banks shall be complied with by the Securities and Exchange Board of India (SEBI) [8]. All of these SEBI laws and regulations require banks to follow ICAI accounting standards. In addition, in compliance with the 1999 legislation, banks in India are required to communicate to the Insurance Regulatory and Development Authority and disclose their insurance business affairs.

Over the years, the huge assets and liabilities of Indian banks have also come to be accompanied by equally large loan loss portfolios (impaired loans or Non Performing Assets, as they are popularly called in India in its accounting parlance) [9]. Of the 16 IFRS prescribed by IASB so far, IFRS-9 is predominantly applicable for implementation in banks, as it stipulates evaluation, disclosure, and presentation of banks' assets and liabilities. Application of the IFRS-9 model to Indian banks has brought in hurdles in the following areas of banks' finance and accounts:

1. Calculation of Loan losses (Loan Impairments)

2. Evaluation of Financial Security Instruments

3. Computation of Tax reportings

4. Hedge Accounting (especially accounting for the risk-hedging products acquired by banks in their Foreign Exchange business)

\section{Impact of IFRS 9 on Banks:}

\section{Credit Losses:}

Reported credit losses are required to increment and become more unpredictable under the new anticipated credit loss model. The number and unpredictability of decisions are additionally expected to increment.

\section{Classification and Measurement:}

How financial assets are grouped turns out to be more judgemental and may influence how capital assets and necessities are determined or calculated.

\section{Hedge Accounting:}

Hedge accounting is all the firmer lined up with risk management and is accessible for a more extensive scope of hedging techniques or strategies.

\section{Disclosures:}

Extensive new disclosures are required as the framework and controls changes will be vital to catching the required information.

IFRS 9 financial instruments significantly change the financial reporting landscape for how entities account for financial instruments. To prepare all financial statements using new accounting standards entities to need to be across the changes they need to make. The changes required can be complex.

Proper adoption of IFRS 9 includes the preparer settling on various decisions concerning how to apply the standards, including deciding as to which transition route to employ. As the decisions made will influence how the performance of a business is estimated and revealed, it is indispensable to think about the commercial and practical issues, yet besides the tax implication of these changes.

\section{Steps to implementation of IFRS 9:}

The appropriation of IFRS 9 should be seen as three extremely particular tasks:

\section{Impact of changes to classification and measurements $(\mathrm{C \& M})$.}

- Identifying all financial assets

- $\quad$ Separating into their classification under IAS 39

a). Held to maturity:

i). Determine if passes the Solely Payments of Principal and Interest (SPPI) test.

ii). Determine if passes hold to collect test.

b). Loans and Receivables:

i). Determine if passes the Solely Payments of Principal and Interest (SPPI) test.

ii). Determine if passes hold to collect test.

c). Fair value profit and loss (held for trading) in case of equity and debt instruments

d). Available for sale:

i). Both for equity and debt instruments, whereas equity instruments must determine if going to classify as Fair value other comprehensive income and debt instruments 
Determine if passes Solely Payments of Principal and Interest (SPPI) test.

ii). Determine if passes hold to collect test.

\section{Impact of moving to a predictive impairment} model.

- Determining which assets will use the Lifetime model versus the Three-stage model

a). For Lifetime model:

i). Develop a predictive impairment model to recognize lifetime losses.

b). For Three-stage model:

i). Determine a method for identifying for 12-month impairment event.

ii). Determine a method for identifying significant deterioration in credit risk.

iii). Determine a method for identifying (i) and (ii).

\section{Opportunities to apply the more relaxed hedging model.}

- Consider whether the entity is exposed to currency risk, interest rate risk, and/or commodity risk.

- Consider whether the entity wishes to apply hedge accounting concerning these risks.

Another hitherto unforeseen hassle in integrating Indian banks' financial affairs into the IFRS model has arisen in the shape of compliance with the guidelines of the Basel Committee on Banking Supervision (BCBS) relating to banks' maintenance of Capital Adequacy and Provisioning against their impaired assets (internationally known as the Basel Accord No. III) [10]. The members of this Committee are the Central Banks of the member-nations (Reserve Bank of India, in case of India). These guidelines are formulated by the Bank for International Settlements (BIS)and are independent of the IFRS.

The ICAI is already ready with its version of global accounting standards, called IND-AS, which is very close to the requirements of IFRS. The president of IASB, who was with ICAI in India a couple of years ago, expressed his satisfaction over the near $100 \%$ convergence of the IND-AS with IFRS. The corporate world of India has already adopted and integrated into IND-AS effective April 2016. However, for the reasons mentioned above, IND-AS has not yet been implemented in the Indian banking sector.

These new regulations are expected to be added to banks, in particular their loan loss provisions, the expense of higher capital requirements. In order immediately to comply with the accounting rules, it is estimated that the government banks could need an additional INR1.1 lakh crore. As a partner of Price Waterhouse and Cooper $(\mathrm{PwC})$, the international auditing firm of repute, has observed: "Balance sheets of Indian banks, especially the
Public Sector ones, are not robust to deal with the impact of the implementation of the new accounting norms" [11]. Also, he said further, "the ongoing merger of Public Sector banks is expected to create more complications on the calculations of "expected loss accounting", the principle prescribed in the new accounting standards". It is therefore beneficial and realistic to drive IND-AS for a couple of years [12]. While the RBI assessed its implications for IND-AS' implementation in 2016, the new system has already provided Indian banks with parallel accounts. The RBI has declared that IND-AS will be postponed until further notice in March 2019.

The International Financial Reporting Standard (IFRS) 9 , which allows for the early identification of losses on loans and non-balancing sheet exposures, is consistent with the Indian Accounting Standards IND-AS, in the sense of the "Expected Credit Loss (ECL)" model. Indian banks are currently following the GAAP (Generally Accepted Accounting Principle) which requires banks to recognize the loss of "Market-to-Market (MTM)" (market-to-market) accounts. However, IND-AS expects its financial statements to improve its clarity and comparability with its global counterparts. It will also have an impact on main functional areas such as regulatory reporting and equity ratios.In2018, banks globally introduced new accounting principles and saw their loan loss provisions rise marginally.

The IFRS 9 is shifting from the "credit loss incurred" model to the "credit loss predicted" model, meaning a time-limit for loss identification may be set. As a result, the supply must be raised and the capital adequacy ratio will be impacted in turn [13]. The Indian banks model of " incurred credit loss" is based on current RBI guidelines where the loan is deducted by how many days before being listed as a stressed asset. On the other hand, the current model will make banks factor in economic cycles and it is to be decided if the health of a borrower, in conjunction with this current "expected credit loss" model, would have a possible bubble [14]. That is before there is any sign of it going bad, banks will have to measure the likelihood of credit is bad.

The government of India has only recently merged 10 government-owned banks to create 4 big banks. This merger has increased its capital adequacy requirement. This is all the more so because these banks are currently saddled with almost INR one lakh crore of stressed loans. The Government of India just does not have the kind of cash at present needed to infuse fresh capital into these banks to boost their business operations. At such a juncture, if the IND-AS (which is the Indian version of IFRS) is implemented, still a higher incremental provisioning requirement will rise because of its "expected credit loss" accounting method. The Government of India and its banking regulator the RBI are just not prepared for such an eventuality. It is informed that the full-fledged transition to IFRS by Indian banks 
has been deferred till 2023.

\section{Conclusions}

Undoubtedly, IFRS has got the mettle to bring inconsistency in the presentation and preparation of financial statements across the globe. This will imperatively also help the users of financial statements around the world to comprehend the information about the financial statements alike. The Indian scenario of the banking sector does have some hurdles in place that are slowing down the IFRS implementation pace. But these regulatory agencies are working to the best of their ability to make this necessary reform and it will be a day when the Indian banking industry is completely prepared with the global modus operandi to help the global financial regulators' understanding. The implementation of IFRS not only enhances the credibility of the bankers and this transparency will enhance the business of the banks internationally. This will bring more international customers to the bank and will also lead to the contribution to the economic growth of the country.

\section{REFERENCES}

[1] Adzis, A., Tripe, D., \& Dunmore, P., "International Financial Reporting Standards (IFRS) and Income Smoothing Activities of Banks: Evidence from Australia and New Zealand Commercial Banks," SSRN Electronic Journal, 2010. https://doi.org/10.2139/ssrn.1717307

[2] BALL, R., LI, X., \&SHIVAKUMAR, L., "Contractibility and Transparency of Financial Statement Information Prepared Under IFRS: Evidence from Debt Contracts AroundIFRS Adoption," Journal of Accounting Research, 53(5), 915-963, 2015. https://doi.org/10.1111/1475-679x.1 2095

[3] Baumann, U., \&Neir, E., "Disclosure, Volatility, and transparency: An empirical investigation into the value of bank disclosure," Federal Reserve Bank of New York Economic Policy Review, September, pp. 31-45, 2004.

[4] Ben Hamida, N., "European Banks Confronted to
IAS/IFRS 39," SSRN Electronic Journal, 2005. https://doi.org/10.2139/ssrn.675002

[5] Biolon, J., Gambong, S. M., Ocoy, V., Quibal, P., \& Tan, J., "Compliance Scorecard on Financial Risk Management Disclosure (IFRS 7): Evidences among Publicly-Listed Banks in the Philippines,"SSRN Electronic Journal, 2017. https://doi.org/10.2139/ssrn.2992243

[6] Felski, E., "How Does Local Adoption of IFRS for Those Countries That Modified IFRS by Design, Impair Comparability with Countries That Have Not Adapted IFRS?," Journal of International Accounting Research, 16(3), 59-90, 2017. https://doi.org/10.2308/jiar-51807

[7] Gebhardt, G., Mora, A., \&Wagenhofer, A., "Revisiting the Fundamental Concepts of IFRS," Abacus, 50(1), 107-116, 2014. https://doi.org/10.1111/abac. 12024

[8] K. Almasarwah, A., M. Omoush, A., \&Alsharari, N., "IFRS compliance and stock prices influence: evidence from Jordanian banks," Banks And Bank Systems, 13(3), 24-35, 2018. https://doi.org/10.21511/bbs.13(3).2018.03

[9] Lejard, C., "How Do Banks Account for Short-Term Effects of IFRS 9?," SSRN Electronic Journal, 2016. https://doi.org/10.2139/ssrn.2890225

[10] Lin, S., "Discussion of the Determinants and Consequences of Heterogeneous IFRS Compliance Levels Following Mandatory IFRS Adoption: Evidence from a Developing Country," Journal Of International Accounting Research, 11(1), 113-118, 2012. https://doi.org/10.2308/jiar-10226

[11] Pospíšil, J., "IFRS 3 COMPLIANCE RESEARCH AT CZECH CAPITAL MARKET," ActaAcademicaKarviniensia, 17(1), 76-86, 2017.https://doi .org/10.25142/aak.2017.007

[12] Ram, R., \& Newberry, S., "IFRS FOR SMEs: THE IASB'S DUE PROCESS," Australian Accounting Review, 23(1), 3-17, 2012. https://doi.org/10.1111/j.1835-2561.2012.0017 $4 . \mathrm{x}$

[13] Slaheddine, T., "Non-GAAP and IFRS Earnings Disclosure Case of French Companies," Account and Financial Management Journal, 2017. https://doi.org/10.18535/afmj/v $2 \mathrm{i} 1.03$

[14] Uwuigbe, U., Love Uyoyoghene, A., Jafaru, J., RantiUwuigbe, O., \&Jimoh, R., "IFRS adoption and earnings predictability: evidence from listed banks in Nigeria," Banks And Bank Systems, 12(1), 166-174, 2017. https://doi.org/10.21511/bbs.12(1-1).2017.10 